\title{
New Brazilian species of Asphondyliini (Diptera, Cecidomyiidae)
}

\author{
Maria Virginia Urso-Guimarães ${ }^{1}$ \\ Dalton de Souza Amorim²
}

\begin{abstract}
Asphondylia canastrae sp. nov. (Minas Gerais, Delfinópolis), A. sanctipetri sp. nov. (São Paulo, Ribeirão Preto), and Schizomyia tuiuiu sp. nov. (Mato Grosso, Cuiabá) are described. A. canastrae sp. nov. is associated with Hyptis sp. (Lamiaceae), A. sanctipetri sp. nov. with Didymopanax morototoni (Araliaceae), and S. tuiuiu sp. nov. with Bauhinia rufa (Fabaceae). Illustrations of the new species and comments about their systematic position are presented.
\end{abstract}

Keywords. Asphondylia; Cecidomyiidae; Neotropical; Schizomyia; taxonomy.

\section{INTRODUCTION}

The family Cecidomyiidae has four subfamilies: Catotrichinae, Lestremiinae, Porricondylinae, and Cecidomyiinae (JASCHOFF 2000). The last one includes the gall maker species in four supertribes, one of which is the Cecidomyiidi, with nine tribes. Most of these tribes have worldwide distribution, including the Asphondyliini. Two subtribes have been ascribed to the tribe, the Asphondyliina with nine genera and Schizomyiina with 12 genera. In this paper, two new species of Asphondylia Loew, 1850 and one of Schizomyia Kieffer, 1889, are described.

Asphondylia is cosmopolitan, with more than 270 described species, of which about 100 occur in the Neotropical Region, 16 in Brazil (GAgNÉ 1994; Gagné \& WuensChe 1986; GagnÉ \& Waring 1990; Gagné \& Orphanides 1992; Skuhravá 1986; Grover 1991; Maia 1992; MaIA 2001a). Schizomyia is also cosmopolitan in distribution, with 42 described species; there are four described Neotropical species. GAGNÉ (1994) considers Schizomyia a catchall genus for species with needlelike ovipositors, four-segmented palpi, and larvae with four pairs of terminal papillae.

Galls of Asphondylia species have been found in different organs of an array of plant families. One of the Asphondylia species described here was collected in inflorescence floral tubes of an unidentified species of Hyptis Jacq. (Lamiaceae) in a ciliar forest area of Ribeirão Preto (SP). The other species was collected in swollen petioles and leaves of Didymopanax morototoni (Aubl.) Decne. \& Planch (Araliaceae) in a ciliar forest area of Delfinópolis (MG). Araliaceae is a new family and Hyptis a new genus of host plant for Asphondylia. Schizomyia species have been found before in the Neotropical Region in flower buds of Ipomea sp. All. (Convolvulaceae) (FeLT 1910), in leaves of Manihot utilissima Pohl. (Euphorbiaceae) (TAVARES 1925), in deformed flowers of Serjania goniocarpa Radlk (Sapindaceae) (Möнn 1960), in seeds of Stachytarpheta cayennensis (Rich.) M. Vahl (Verbenaceae) (BARNES 1932), and in closed flowers of Jacquemontia holosericea (Weinman) O'Donell (MAIA 2001b). The species of Schizomyia described here was collected from hairy galls in leaves of Bauhinia rufa (Bong.) Steud. (Fabaceae) in a cerrado area of Cuiabá (MT).

\section{MATERIAL AND METHODS}

Galls of Asphondylia were collected in Ribeirão Preto (State of São Paulo) and Delfinópolis (State of Minas Gerais), in natural vegetation areas during winter. The galls of Schizomyia were collected in Cuiabá (State of Mato Grosso), during summer in a cerrado in an urban area. Collected galls were transferred to individual plastic bags, for rearing the adults. Some of the galls were dissected under stereomicroscope to obtain immature. All material was conserved in $70 \%$ alcohol. Slide mounting technique follow GAGNÉ (1994). The nomenclature of thoracic setae position follows SAETHER (1980) and Söli (1997). The

1. Departamento de Biologia, FFCLRP/USP. Av Bandeirantes, 3900, 14900-401 Ribeirão Preto - SP, Brazil. E-mail: mvirgini@usp.br. Bolsista FAPESP \# 99/01429-1.

2. Departamento de Biologia, FFCLRP/USP. Av Bandeirantes, 3900, 14900-401 Ribeirão Preto - SP, Brazil. E-mail: dsamorim@usp.br. Pesquisador CNPq. 
holotype and paratypes of Asphondylia canastrae sp. nov., A. sanctipetri sp. nov., and Schizomyia tuiuiu sp. nov. are deposited in the Museu de Zoologia-USP, São Paulo (MZSP).

\section{Asphondylia canastrae sp. nov.}

(Figs. 1-12)

Description. Adult (male). Body length, $3.2 \mathrm{~mm}$; maximum width, $0.9 \mathrm{~mm}$. Head (Fig. 1) length, $0.5 \mathrm{~mm}$; maximum width, 0.6 $\mathrm{mm}$. Eyes black, not divided in vertex, occiput light brown with long hairs; eye facets hexagonal, closely adjacent. Antennae total length, $2 \mathrm{~mm}$; scape length, $0.12 \mathrm{~mm}$; maximum width, 0.05 $\mathrm{mm}$; scape broader distally; pedicel length and maximum width, $0.05 \mathrm{~mm}$; 12 cylindrical flagellomeres, becoming successively shorter in length from base to apex in females, first and second flagellomeres $0.2 \mathrm{~mm}$ length; third to tenth, since 0.18 to 0.16 $\mathrm{mm}$; eleventh, $0.15 \mathrm{~mm}$ and twelfth, $0.14 \mathrm{~mm}$ length in male; circumfila sinuous in male and straight in female as in Figs. 2 and 3. Twenty setae in the frons and clipeous bare. Labellum length, $0.08 \mathrm{~mm}$, completely setose at distal portion; palpus total length, $0.16 \mathrm{~mm}$; palpus 2-segmented, palpus base, 0.02 $\mathrm{mm}$ length; first palpomere $0.05 \mathrm{~mm}$, and second, $0.08 \mathrm{~mm}$; both cylindrical, setae number and position as in Fig. 4. Thorax: Dorsal region of antepronotal lobe with a group of setae. Scutum and scutelum light brown, fused only in the dorsal portion; scutum, $0.7 \mathrm{~mm}$ length; one row of dorsocentral setae, lateral prealar (or humeral) and postalar setae joined in a unique row in the scutum; scutelum completely covered by setae; anepistern with eighteen setae; katepistern bare; anepimeron with three rows of setae in its middle portion; mediotergite bare; laterotergite with three trichoid sensila near halter base. Legs: First coxa with two trichoid sensila groups, one with three and other with four in the proximal position, and setae covering the distal portion; spur of first tarsomere, $0.03 \mathrm{~mm}$ in forelegs; and $0.02 \mathrm{~mm}$, in the middle and hind legs; tarsal claws without tooth in all legs (Fig. 5), bent beyond midway to apex; $0.05 \mathrm{~mm}$ in forelegs; and $0.04 \mathrm{~mm}$, in the middle and hind legs; empodia smaller than claws, $0.03 \mathrm{~mm}$ in all legs. Wing length, $2.9 \mathrm{~mm}$, maximum width, $1.1 \mathrm{~mm}$; halter length, $0.5 \mathrm{~mm}$, both covered with setae and scales. Abdominal tergites and sternites completely covered by hair like setae and scales; tergites and sternites weakly sclerotized in males, and well sclerotized in females. Male terminalia (Fig. 6): gonocoxite length and maximum width, $0.2 \mathrm{~mm}$; gonostylus, length and maximum width, 0.08 $\mathrm{mm}$; hypoproct length, $0.08 \mathrm{~mm}$, aedeagus length, $0.04 \mathrm{~mm}$; cercus length, $0.12 \mathrm{~mm}$.

Female. Ovipositor (Fig. 7) six times longer than S7; ovipositor length, $3.2 \mathrm{~mm}$; S7 length, $0.5 \mathrm{~mm}$; needlelike to apex, with few setae; cerci like lobes present; cercus fused.

Pupa (Figs. 8, 9, 10). Body light brown. Body length, $5 \mathrm{~mm}$; maximum width, $1.1 \mathrm{~mm}$. Cephalic region (Fig. 8); cephalic setae short, $0.04 \mathrm{~mm}$ length; antennal horns medium size, $0.6 \mathrm{~mm}$ length, serrate in inner edge; upper frontal horn short, $0.04 \mathrm{~mm}$ length, simple; lower frontal horn short, $0.05 \mathrm{~mm}$ length, trifid, medium tooth smaller than lateral; two pairs of lower facial papillae (one setose and one bare), three pairs of lateral papillae (one setose and two bare) (Fig. 9). Thorax: prothoracic spiracle short, $0.09 \mathrm{~mm}$ length, cylindrical, wing reaching third abdominal segment; legs reaching fifth abdominal segment; second pair smaller than first and third. Abdomen: Two-sclerotized row of spines $(0.02-0.04 \mathrm{~mm}$ length) on tergites $3-8$ and terminal segment. Terminal segment with strong, sclerotized, hooked spines (Fig. 10). Pupation in gall.

Larva. Third instar. Body length, $1.6 \mathrm{~mm}$, maximum width, $0.9 \mathrm{~mm}$, cream. Prothoracic spatula length, $0.1 \mathrm{~mm}$, maximum width, $0.02 \mathrm{~mm}$; with four teeth of equal size; lateral papillae in two reduced groups one with one and other with 2 setose papillae (Fig. 11). Terminal segment broken.

Holotype male (emerged on flower galls of an unidentified species of Hyptis sp.). Brasil, Minas Gerais, Delfinópolis, Estância Carmen Silvia, ciliar forest. Collection: 29.VI.2000, emergence: 13.VII.2000. Urso-Guimarães, M.V.\& Scareli-Santos, C. col. (MZSP). Paratypes. Same data as holotype, except for, 1 female, emergence, 12.VII.2000; 5 exuviae; 3 pupae, 2 teneral females, 1 larva. (MZSP).

Gall. In the flowers of the inflorescence of an unidentified species of Hyptis Jacq. (Lamiaceae), the larvae/pupae occupied the position of the original ovary. The flowers were not modified, and immatures were not perceptible before the flower opens (Fig. 12).

Differential diagnosis. Twenty setae in the frons and clipeous bare; laterotergite with three trichoid sensila near halter base; scutum and scutelum fused only in the dorsal region; first coxa with two trichoid sensila groups; ovipositor six times longer than S7 length; presence of hooked spines in the pupal terminal segment; galls in flowers of Hyptis sp. (Lamiaceae).

Etymology. The species is named after the "Serra da Canastra" region, a range in the boundary between the Paraná and São Francisco river basins.

\section{Asphondylia sanctipetri sp. nov.}

(Figs. 13-24)

Description. Adult (male). Body length, $3.2 \mathrm{~mm}$; maximum width, $0.6 \mathrm{~mm}$. Head (Fig. 13): length, $0.4 \mathrm{~mm}$; maximum width, $0.3 \mathrm{~mm}$. Eyes black, not divided in vertex; eyes facets hexagonal, closely adjacent. Antennae total length, $1.6 \mathrm{~mm}$; scape length, $0.12 \mathrm{~mm}$; maximum width, $0.05 \mathrm{~mm}$; broader distally, pedicel length and maximum width, $0.04 \mathrm{~mm} ; 12$ cylindrical flagellomeres; becoming successively shorter in length from base to apex in females; first flagellomere $0.2 \mathrm{~mm}$ length; second to tenth, since 0.16 to $0.10 \mathrm{~mm}$; eleventh, $0.06 \mathrm{~mm}$ and twelfth, $0.04 \mathrm{~mm}$ length in female; circumfila sinuous in male and straight in female as in the Figs. 14 and 15. Thirteen setae in the frons and three in the 

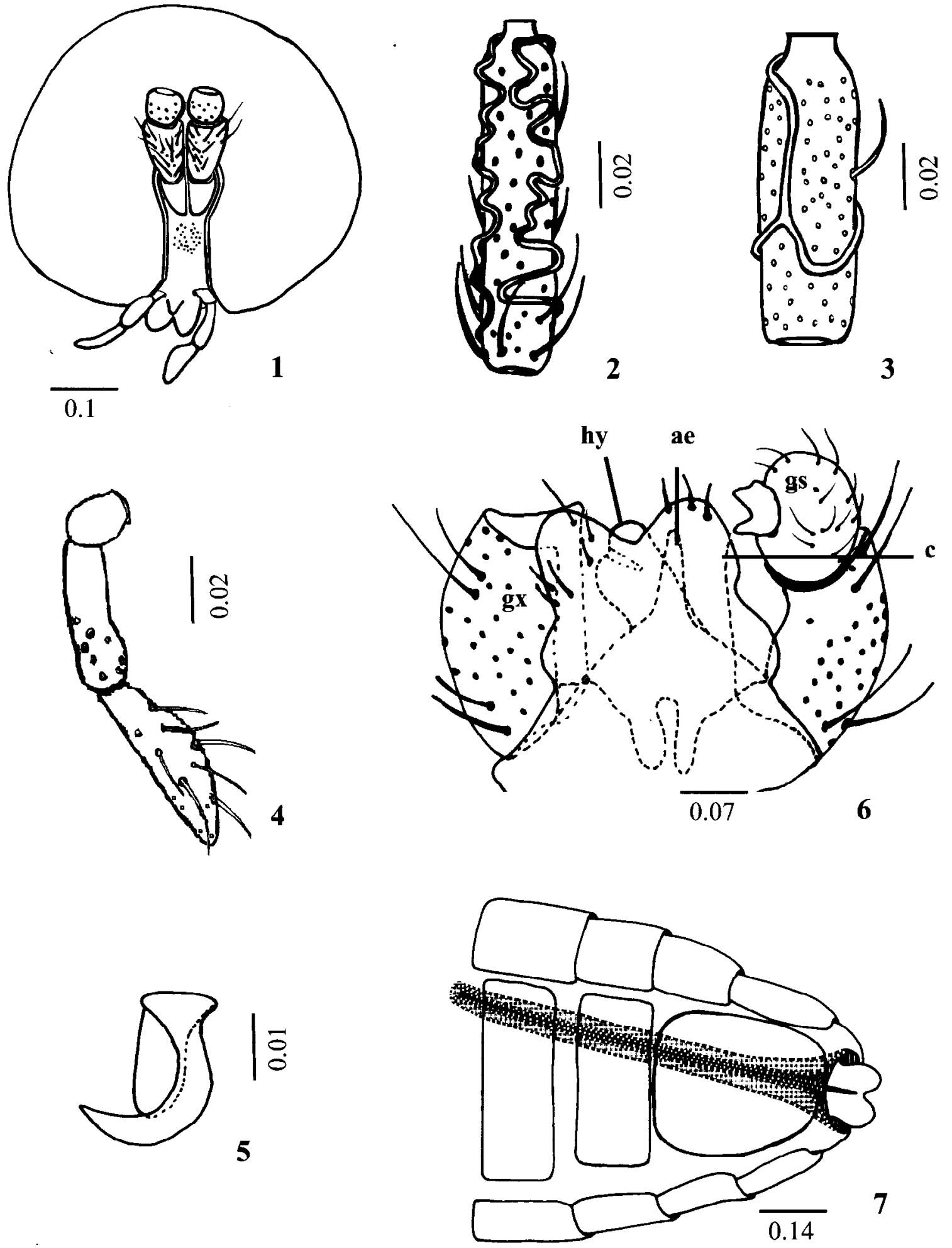

Figs. 1-7. Asphondylia canastrae sp. nov. : 1, head (frontal view); 2, flagellomere-3 of male; $\mathbf{3}$, idem of female; $\mathbf{4}$, palpus; $\mathbf{5}$, tarsal claw of middle leg; 6, male terminalia; 7, posterior region of female abdomen, internal structures doted. Abbreviations: ae, aedeagus; c, cercus; gs, gonostylus; gx, gonocoxites; hy, hypoproct. (Scale bar in $\mathrm{mm}$ ). 

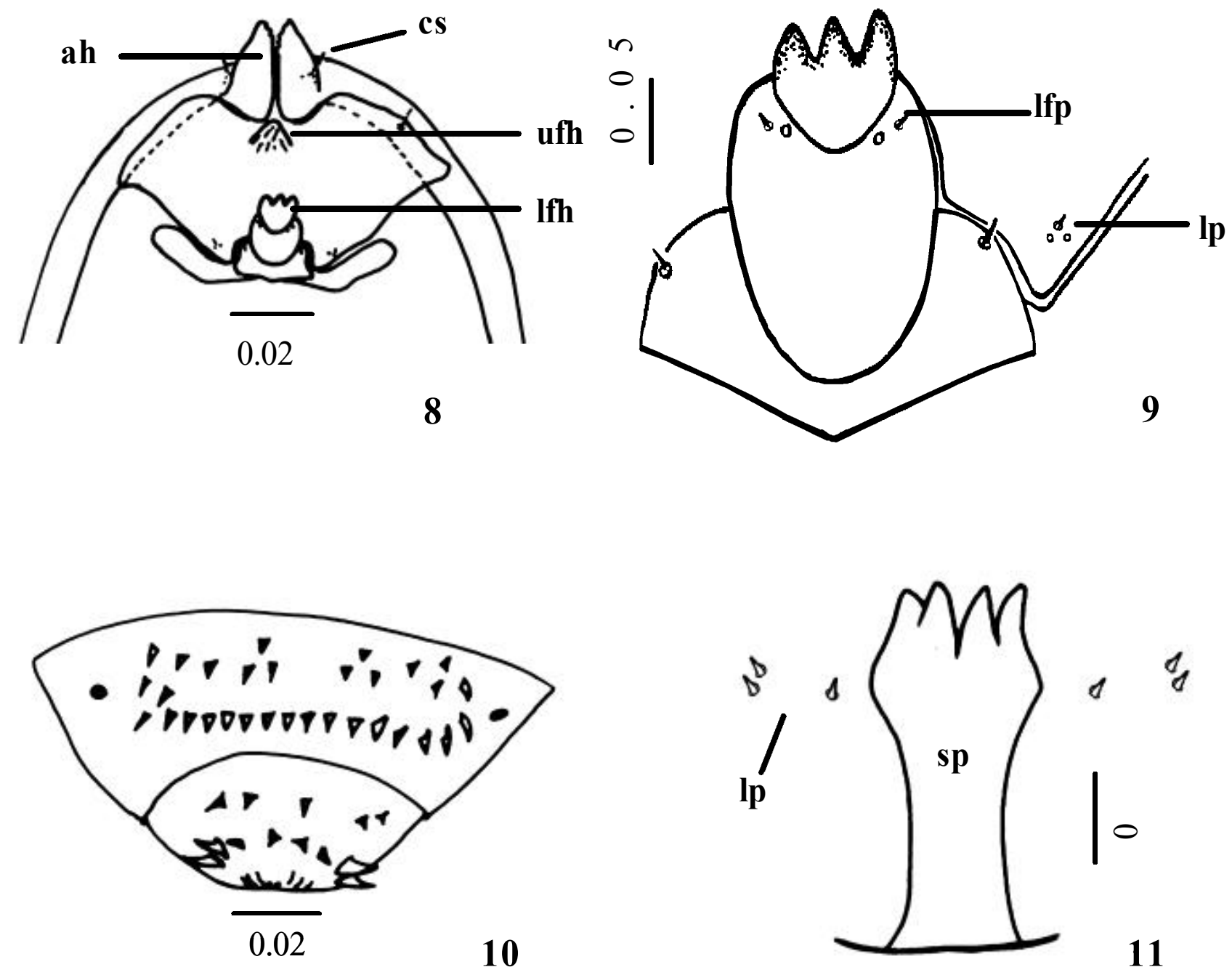

Figs. 8-11. Asphondylia canastrae sp. nov. : 8, pupa head (frontal view); 9, detail of pupa head papillae; 10, pupa terminal segment (dorsal view); 11, larval prothoracic spatula and lateral papillae. Abbreviations: ah, antennal horn; cs, cephalic setae; 1fh, lower frontal horn; lfp, lateral facial papillae; lp, lateral papillae; ufh, upper frontal horn. (Scale bar in $\mathrm{mm}$ ).

clipeous. Labellum length, $0.04 \mathrm{~mm}$, completely setose at distal portion; palpus total length, $0.2 \mathrm{~mm}$; palpus 2-segmented, palpus base, $0.03 \mathrm{~mm}$ length; first palpomere $0.08 \mathrm{~mm}$, and second, $0.09 \mathrm{~mm}$; both cylindrical, setae number and position as in Fig. 16. Thorax: Antepronotal lobe with a group of hair like setae in the median dorsal region. Scutum and scutelum dark brown, fused only in the dorsal portion; scutum length, $0.5 \mathrm{~mm}$, with one row of dorsocentral setae, lateral prealar (humeral) and postalar setae joined in a unique row; scutelum completely covered by setae; anepistern with 11 scales; katepistern bare; three rows of hair like setae in the middle portion of anepimeron; mediotergite bare; laterotergites with two trichoid sensila at halter base. Legs: First coxa with one trichoid sensila group, with four in the proximal position, and hair like setae covering the distal portion; spur of first tarsomere, $0.02 \mathrm{~mm}$ in all legs; tarsal claws without tooth in all legs (Fig. 17), bent beyond midway to apex; $0.04 \mathrm{~mm}$ in all legs; empodia smaller than claws, $0.03 \mathrm{~mm}$ in all legs. Wing length, $2.4 \mathrm{~mm}$, maximum width, 0.9 $\mathrm{mm}$; halter length, $0.4 \mathrm{~mm}$, both covered with setae and scales. Venation as in Fig. 18, R5 joining $\mathrm{C}$ beyond apex. Abdominal tergites and sternites 2-7 with a posterior line of stronger hair like setae, and completely covered by scales; tergites and sternites with complete sclerotization, weakly sclerotized in males, and well sclerotized in females; trichoid sensila absent. Male terminalia (Fig. 19): gonocoxites length, 0.12, maximum width, $0.06 \mathrm{~mm}$, narrow, completely covered with setae, gonostylus length and maximum width, $0.04 \mathrm{~mm}$, rounded, at dorsal portion of gonocoxite, gonostylus teeth entire at base, fended at tip; aedeagus length, $0.12 \mathrm{~mm}$, narrow; hypoproct bilobed, $0.11 \mathrm{~mm}$; cercus length, $0.11 \mathrm{~mm}$, rounded, with few strong setae.

Female body length, $3.8 \mathrm{~mm}$; maximum width, $1.3 \mathrm{~mm}$. 

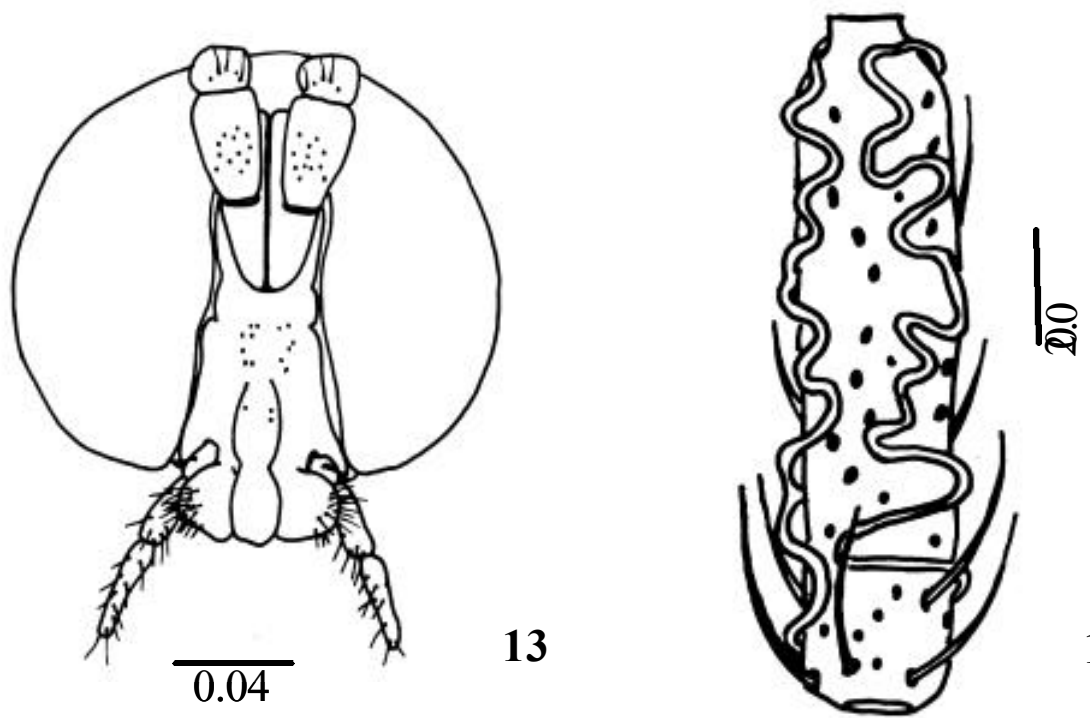

14
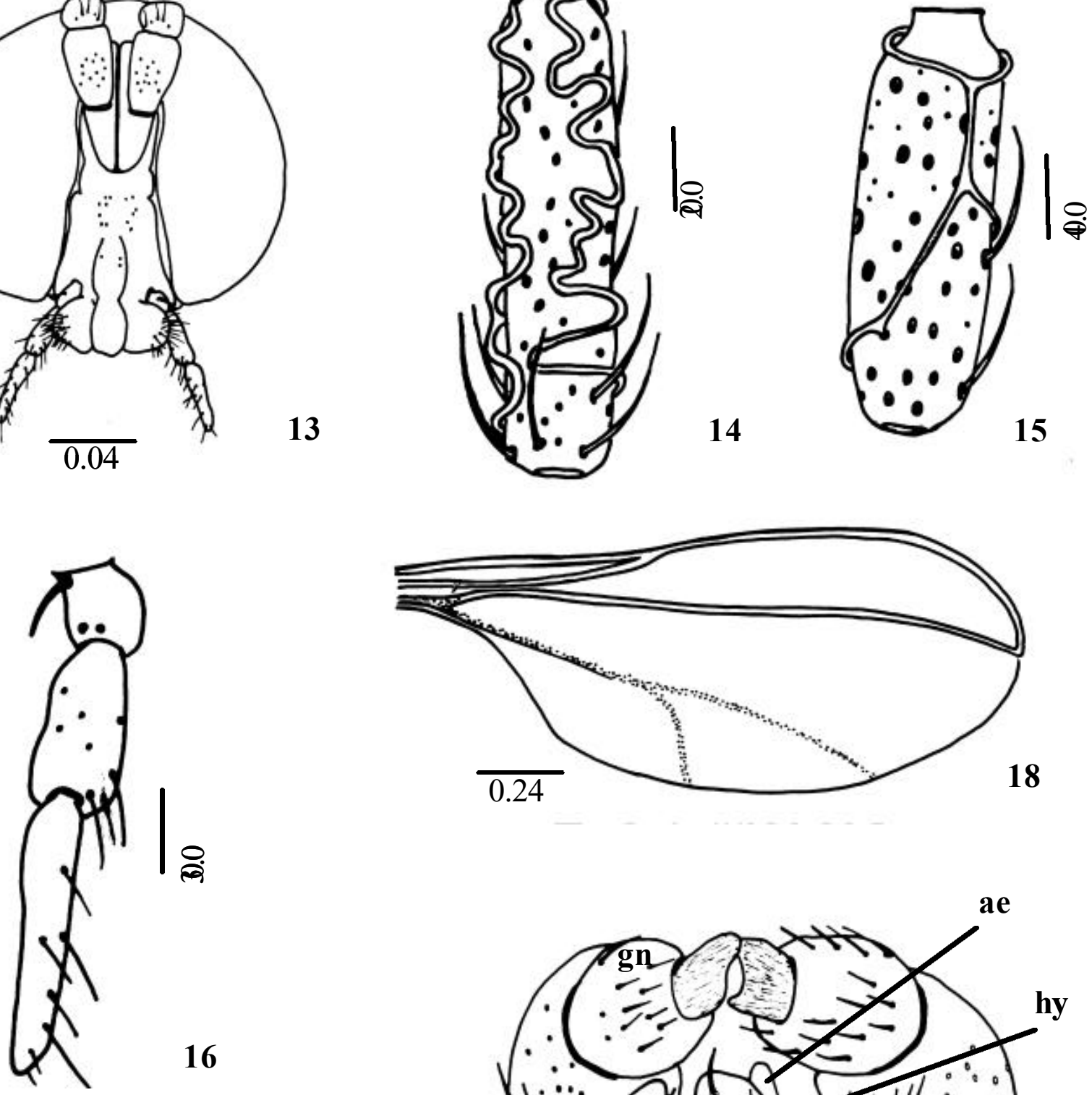

16

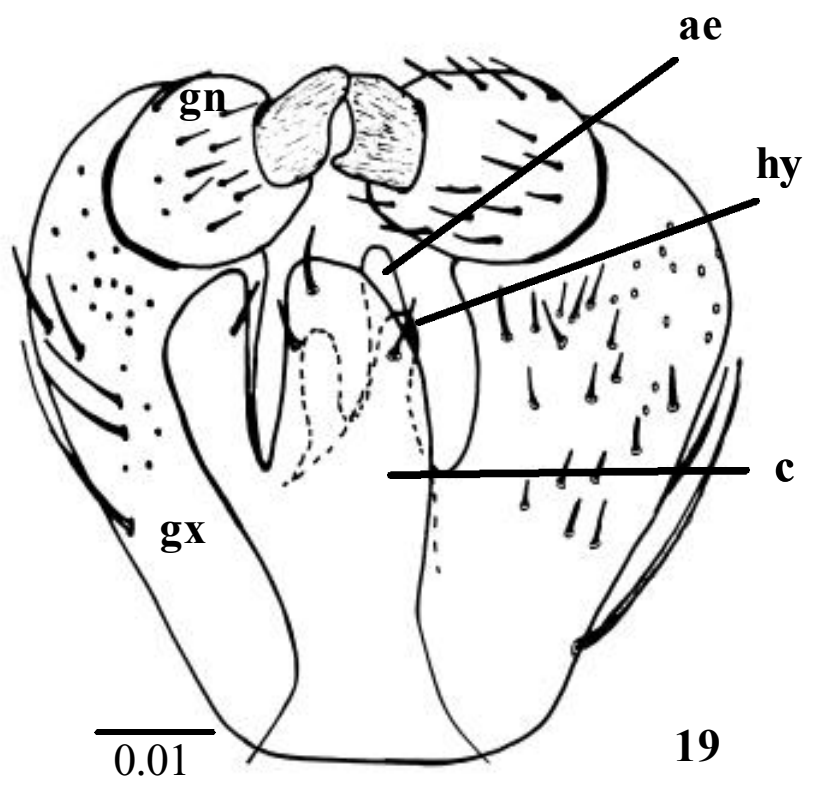

Figs. 13-19. Asphondylia sanctipetri sp. nov. : 13, head (frontal view); 14, flagellomere-3 of male; 15, idem of female (b); 16, palpus; 17, tarsal claw of middle leg; 18, wing; 19, male terminalia (dorsal view). Abbreviations: ae, aedeagus; c, cercus; gn, gonostylus; gx, gonocoxites; hy, hypoproct. (Scale bar in $\mathrm{mm}$ ). 


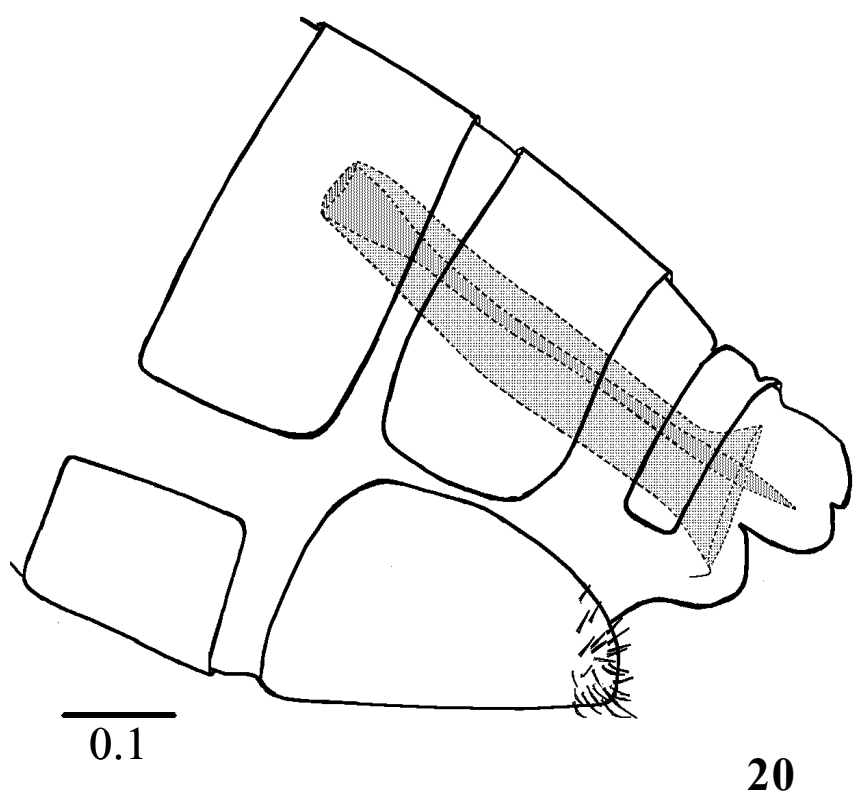

20

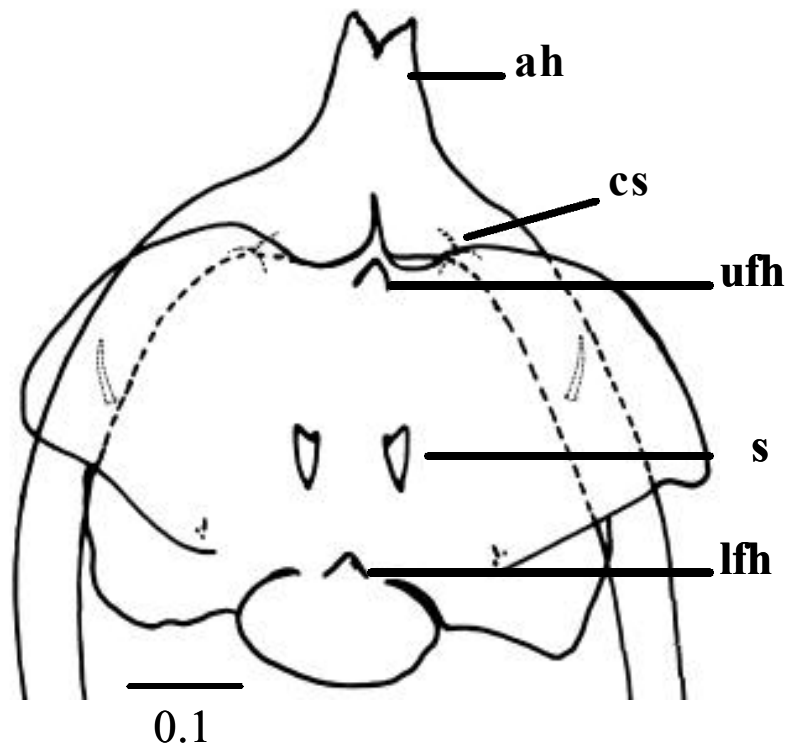

21
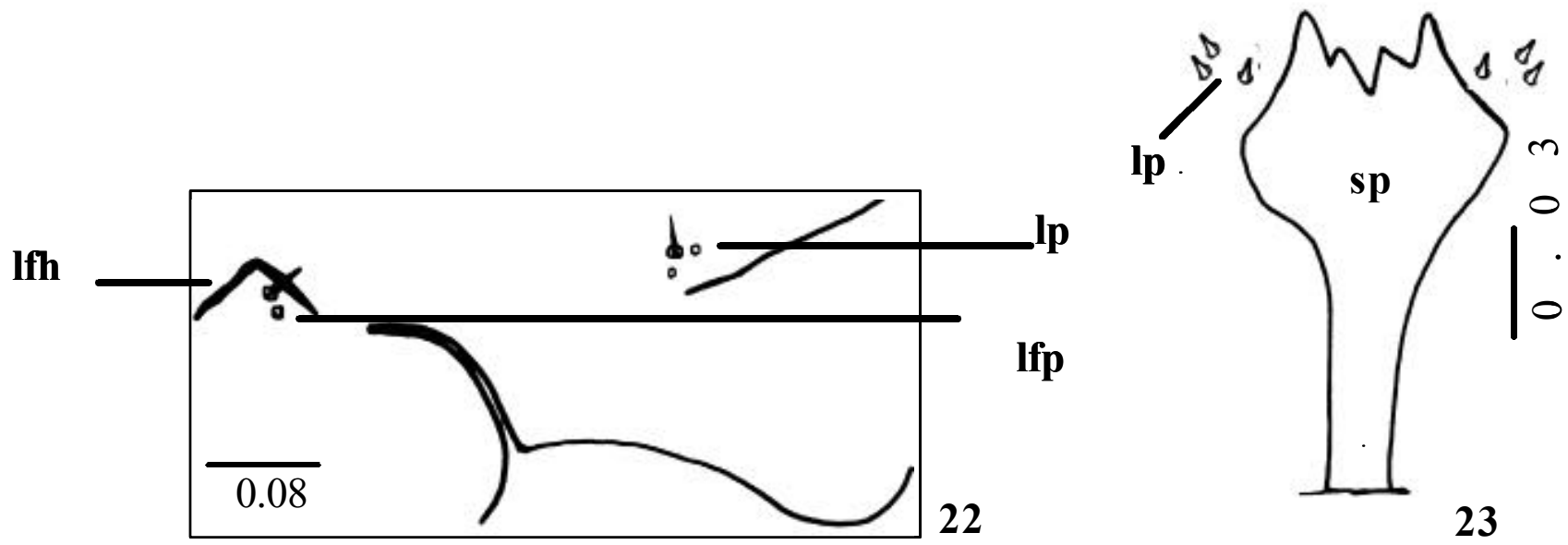

Figs. 20-23. Asphondylia sanctipetri sp. nov. : 20, posterior region of female abdomen; 21, pupa head (ventral view); 22, detail of pupa head papillae; 23, prothoracic spatula and associated papillae. Abbreviations: ah, antennal horn; cs, cephalic setae; lfh, lower frontal horn; lfp, lateral facial papillae; lp, lateral papillae; ufh, upper frontal horn. (Scale bar in $\mathrm{mm}$ ).

Ovipositor (Fig. 20) 3.2 times longer than S7, ovipositor length, $1.64 \mathrm{~mm}$; S7 length, $0.5 \mathrm{~mm}$; needlelike to apex, with few setae; cerci like lobes present; cercus fused.

Pupa (Figs. 21, 22). Body light brown. Body length, $2.8 \mathrm{~mm}$; maximum width, $0.9 \mathrm{~mm}$. Cephalic region(Fig. 21); cephalic setae short, $0.04 \mathrm{~mm}$ length with an associated papillae, antennal horns long, $0.16 \mathrm{~mm}$ length, serrate in the inner edge, upper and lower frontal horn simple, short, upper frontal horn length, $0.08 \mathrm{~mm}$, and lower frontal horn, $0.04 \mathrm{~mm}$; two pairs of lower facial papillae (one setose and one bare), three pairs of lateral papillae (one setose and two bare) (Fig. 22); two strong sclerotized spines between upper and lower frontal horns. Thorax: prothoracic spiracle short, $0.08 \mathrm{~mm}$ length, setiform; wing reaching fifth abdominal segment; first, second and third pairs of legs reaching eighth abdominal segment, second pair smaller than first and third. Abdomen: one simple and continuous row of sclerotized spines (0.02-0.04 mm length) in the distal edge on the tergites 3-8 and terminal segment. Pupation in gall.

Larva. Third instar. Body length, $1.9 \mathrm{~mm}$, maximum width, $1.1 \mathrm{~mm}$; cream. Prothoracic spatula length, $0.2 \mathrm{~mm}$, maximum width, $0.1 \mathrm{~mm}$; with four teeth, the inner teeth smaller than the 

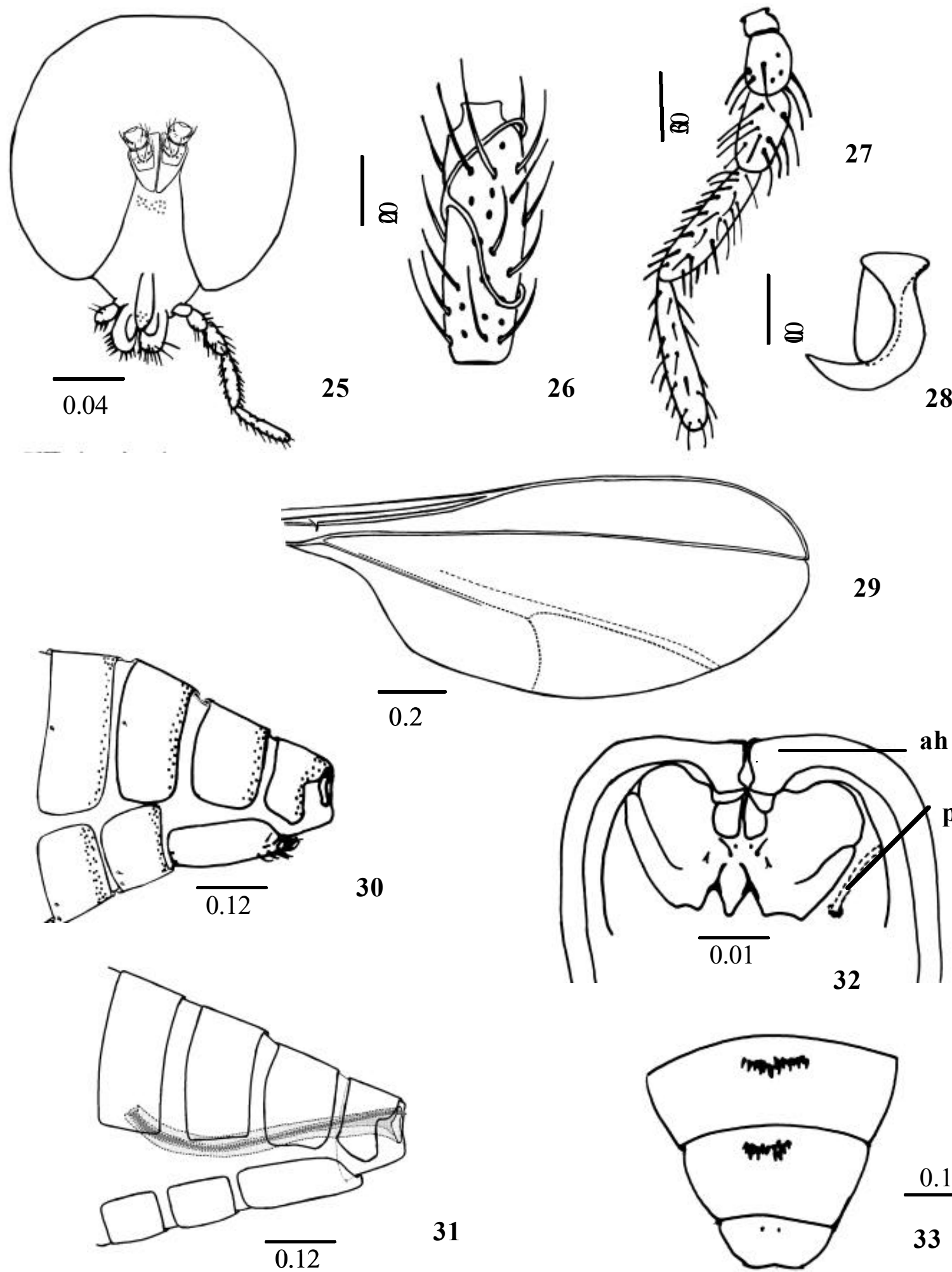

31

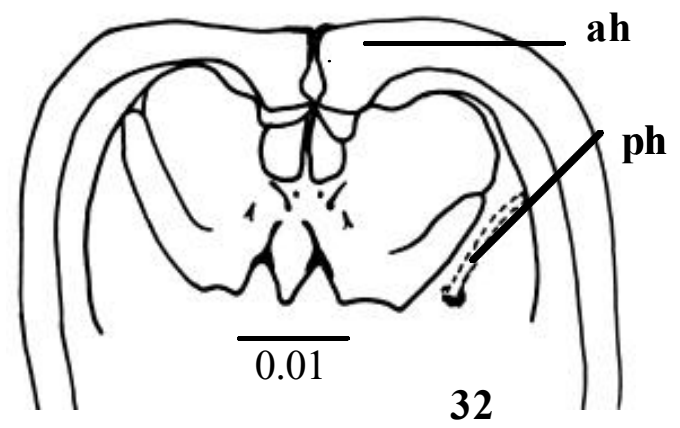

Figs. 25-33. Schizomyia tиiuiu sp. nov.: 25, head (frontal view); 26, flagellomere-3 of female; 27, palpus; 28, tarsal claw of middle leg; 29, wing; 30, external morphology of posterior region of female abdomen; 31, internal structures of posterior region of female abdomen; 32, pupa head (ventral view) and prothoracic spiracle; 33, terminal portion of pupa abdomen (dorsal view). Abbreviations: ah, antennal horn; ph, prothoracic horn. (Scale bar in $\mathrm{mm}$ ). 
external; lateral papillae in two reduced groups one with one and other with 2 setose papillae (Fig. 23). Terminal segment with 2 papillae in each side of anus, one setose and other asetose.

Holotype male (emerged from Didymopanax morototoni leaf vein and petiole galls). Brasil, São Paulo, Ribeirão Preto, Fazenda Palmeiras, forest formation; collection, 23.V.2001, emergence, 28.V.2001. Kotchekoff-Henriques, O. col. (MZSP). Paratypes. Same data of holotype, except for: 1 female (emergence, 02.VIII.2001); 1pupa, 1 exuvia. Brazil, São Paulo, Ribeirão Preto, Fazenda Palmeiras, collection, 23.V.2001, 1 female (emergence, 28.V.2001), 1 larva. (MZSP).

Gall (Fig. 24). In swollen leaf vein and petiole of Didymopanax morototoni (Aubl.) Decne. \& Planch (Araliaceae), green, associated with fungus.

Differential diagnosis. Thirteen setae in the frons and three in the clipeous; laterotergites with two trichoid sensila at halter base; ovipositor about 3.2 times longer than S7. Pupa, two strong sclerotized spines between upper and lower frontal horns; one simple and continuous row of sclerotized spines galls on swollen leaf vein and petiole, green, associated with fungus, in Didymopanax morototoni (Araliaceae).

Comments. Sixteen species of Asphondylia have been described to date from Brazil, seven of which from the State of Rio de Janeiro, two from the State of Rio Grande do Sul, two from the State of Ceará, two from the State of Bahia, one from the State of Amazonas, and two without determined typelocality. MAIA (2001a) reported two additional undescribed species from the State of Rio de Janeiro. Most of these species come from plants in the Atlantic Forest domains, and only some of them may came from open area vegetation. Both species described here come from small ciliar forest patch within open vegetation in southeastern Brazil. The new species of Asphondylia described in this paper can be distinguished from the other described species based on the length of ovipositor relative to S7, to thoracic pupae characters, features of the gall, and the host plant. None of the sixteen described species has the combination of characters presented by the new species, specially considering the specificity of the host plant and the gall maker.

Etymology. This species is named after Saint Peter, very popular in the Brazilian countryside, because the holotype emerged of Saint Peter's day.

\section{Schizomyia tuiuiu sp. nov.}

(Figs. 25-34)

Description. Adult (female). Body length, $3 \mathrm{~mm}$ (ovipositor intruded) to $4 \mathrm{~mm}$ (ovipositor protruded); maximum width, 0.8 $\mathrm{mm}$. Head (Fig. 25): length, $0.4 \mathrm{~mm}$; maximum width, $0.3 \mathrm{~mm}$. Eyes black, not divided in vertex, occiput brown with long hairs; eyes facets hexagonal, closely adjacent. Antennae total length, $1.2 \mathrm{~mm}$; scape length, $0.05 \mathrm{~mm}$; maximum width, 0.04 $\mathrm{mm}$; broader distally, pedicel length and maximum width, 0.04 $\mathrm{mm} ; 12$ cylindrical flagellomeres; becoming successively shorter in length from base to apex in females; first flagellomere $0.16 \mathrm{~mm}$ length; second to seventh, since 0.13 to $0.10 \mathrm{~mm}$; eighth to tenth, 0.09 to $0.07 \mathrm{~mm}$; eleventh, $0.04 \mathrm{~mm}$ and twelfth, $0.02 \mathrm{~mm}$ length in female; circumfila straight in female as in Fig. 26. Fourteen setae in the frons and clipeous bare. Labellum length, $0.09 \mathrm{~mm}$, completely setose at distal portion; palpus total length, $0.3 \mathrm{~mm}$; palpus 4-segmented, palpus base, 0.02 $\mathrm{mm}$ length; first palpomere $0.04 \mathrm{~mm}$, second, $0.05 \mathrm{~mm}$, third, 0.09 , and fourth, $0.11 \mathrm{~mm}$ length; all cylindrical, setae number and position as in Fig. 27. Thorax: Antepronotal lobe with a group of ten setae in the dorsal region. Scutum $(0.4 \mathrm{~mm}$ length) and scutelum ( $0.02 \mathrm{~mm}$ length) light brown, completely fused; one row of dorsocentral setae in the scutum, lateral prealar (or humeral) and postalar setae joined in a unique row; scutelum completely covered by setae; anepistern with upper than 40 setae; katepistern bare; anepimeron with three rows of setae near wing and one row near coxa 2; mediotergite bare; laterotergites with two trichoid sensila at halter base. Legs: First coxa with one group of four trichoid sensila in the proximal position, and setae covering the distal portion; spur of first tarsomere absent; tarsal claws without tooth in all legs (Fig. 28), bent beyond midway to apex; $0.04 \mathrm{~mm}$ in forelegs, $0.03 \mathrm{~mm}$ in mid and hind legs; empodia smaller than claws, $0.03 \mathrm{~mm}$ in forelegs, $0.02 \mathrm{~mm}$ in mid and hind legs. Wing length, $2 \mathrm{~mm}$; halter: $0.4 \mathrm{~mm}$, hyaline. Venation as in Fig. 29, R5 joining C beyond apex; $\mathrm{M} 3, \mathrm{CuA} 1$ and $\mathrm{CuA} 2$ present; covered with setae and scales. Abdomen: tergites and sternites with complete sclerotization, covered with scales and with a posterior line of stronger hair like setae; trichoid sensila present in the tergites 2-7 in the lateral position; sternites 3-7 with trichoid sensila in the median ventral position (Fig. 30). Ovipositor (Figs. 30, 31) five times longer than S7, ovipositor length, $1.5 \mathrm{~mm}$; S7 length, $0.3 \mathrm{~mm}$; needlelike to apex, with few setae cercus separated.

Pupa (Figs. 32, 33). Body length, $5 \mathrm{~mm}$, maximum width, 0.8 $\mathrm{mm}$. Body light brownish. Cephalic region (Fig. 32): cephalic setae, $0.08 \mathrm{~mm}$ length; antennal horns short, $0.04 \mathrm{~mm}$ length, smooth, rounded, upper and lower frontal horns absent, two pairs of lower facial papillae (one setose and one bare), three pairs of lateral papillae (one setose and two bare). Thorax: prothoracic spiracle very long, $0.2 \mathrm{~mm}$ length, cylindrical; wing reaching fourth abdominal segment; first and second pairs of legs reaching fifth abdominal segment, second pair smaller than first, third pair reaching sixth segment; wing reaching fourth abdominal segment. Abdomen: one row of sclerotized strong spines alternated with small spines $(0.02-0.04 \mathrm{~mm}$ length) on tergites 2-7 (Fig. 33), concentrated mid-dorsally on tergites. Pupation in gall.

Male and larva. Unknown.

Holotype female (emerged on Bauhinia rufa leaf galls). Brasil, Mato Grosso, Cuiabá (Universidade Federal de Mato 

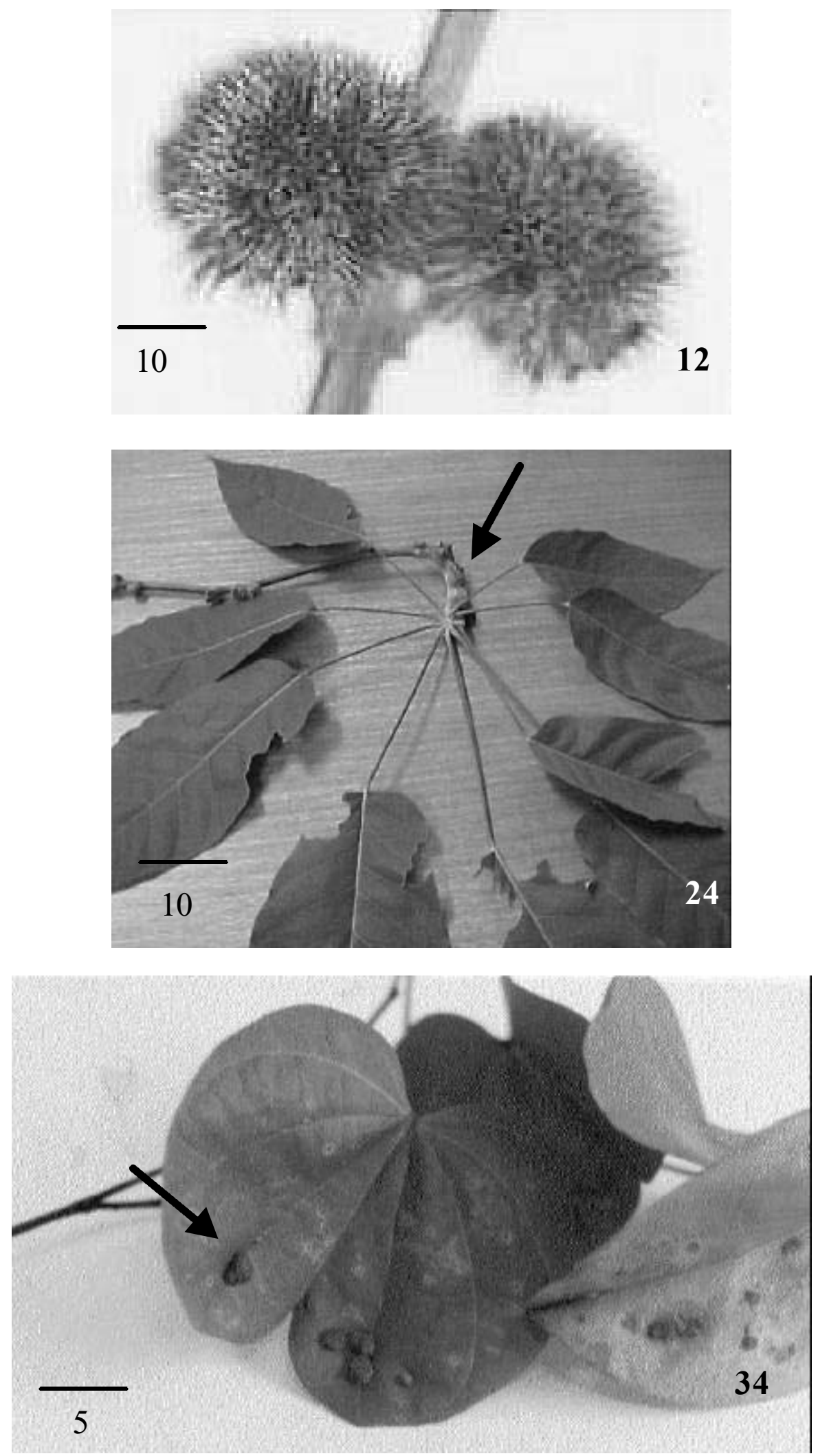

Figs. 12, 24, 34. Gall, general aspect: 12, Asphondylia canastrae sp. nov.; 24, Asphondylia sanctipetri sp. nov.; 34, Schizomyia tuiuiu sp. nov. 
Grosso Campus, at plants in sidewalk near the university Campus Zoo; cerrado formation); collection, 18.II.2000, emergence, 21.II.2000. Urso-Guimarães, M.V. col. (MZSP). Paratypes. Same date as holotype, except for 6 females, emergence, 22.II.2000 (1 female), emergence, 24.II.2000 (3 females); emergence, 25.II.2000 (2 females); 25 exuviae of pupae. (MZSP).

Gall (Fig. 34). Restricted to the leave surface, cream to redbrownish in color, unilocular, extremely hairy, without a definite shape in Bauhinia rufa (Bong.) Steud. (Fabaceae).

Differential diagnosis. Adults. Fourteen setae in the frons and clipeous bare; antepronotal lobe with a group of ten setae in the dorsal region, scutum and scutelum completely fused; laterotergites with two trichoid sensila at halter base; first coxa with one group of four trichoid sensila; ovipositor five times longer than S7. Pupa. Dorsal abdominal spines present.

Comments. There is only one Schizomyia species described, from Brazil, State of Ceará, reared from leaf galls of Manihot utilissima (Euphorbiaceae). The other species were described from Saint Vincent (Ipomea sp., Convolvulaceae), El Salvador (Serjania goniocarpa, Sapindaceae) and Trinidad (Stachytarphetae cayennensis, Verbenaceae). The new species clearly fits in Schizomyia by having the characters of the genus: needlelike ovipositor, palpi four-segmented, and absence of ventroapical spine or spurs on first tarsomere. Other features agree with the descriptions of Schizomyia species, as the flagellomere circumfila shape, the position of setae in the ovipositor, empodia smaller than tarsal claws, and pupae with dorsal abdominal spines (MöHN 1960; TAVAREs 1925).

Etymology. "Tuiuiu" is the popular name for Jabiru mycteria Lichtenstein, 1819 (Ciconiidae), a large bird typical of the Pantanal region.

Acknowledgements. The authors acknowledge Dr. R. J. Gagné (Smithsonian Institution/USDA); M. I. P. Balbi; Dra. C. Scareli-Santos, MSc. A. C. Caboni, MSc. O. Kotchetkoff-Henriques and H. F. Mendes (Depto. Biologia, FFCLRP/USP); FAPESP (Proc. \# 99/01429-1).

\section{REFERENCES}

Barnes, H. F. 1932. Notes on Cecidomyiidae. Annals and Magazine of Natural History (10)9: 475-484.

Felt, E. P. 1910. Schizomyia ipomeae n. sp. Entomological News 21: $160-161$.

Gagné, R. J. 1994. The Gall Midges of the Neotropical Region Ithaca, Cornell University Press, xiv $+352 \mathrm{p}$.

GaGnÉ, R. J. \& A. L. Wuensche. 1986. Identity of the Asphondylia (Diptera: Cecidomyiidae) on Guar, Cyamopsis tetragonoloba (Fabaceae), in the Southwestern United States. Annals of the Entomological Society of America 79: 246-250.

Gagné, R. J. \& G. L. Waring. 1990. The Asphondylia (Cecidomyiidae: Diptera) of Creosote Bush (Larrea tridentata) in North America. Proceedings of the Entomological Society of Washington 92 (4): 649-671.

Gagné, R. J. \& G. M. Orphanides. 1992. The Pupae and Larva of Asphondylia gennadii (Diptera: Cecidomyiidae) and Taxonomic Implications. Bulletin of Entomological Research 82 (313-316)

Grover, P. 1991. Three New Species of Supertribe Cecidomyiidi from India. Cecidologia Internationale 12:1-3.

JASCHOFf, M. 2000. Catotrichinae Subfam. N.: a Re-examination of Higher Classification in Gall Midges (Diptera: Cecidomyiidae). Entomological Science 3(4): 639-652.

MaIA, V. C. 1992. Sobre Seis Espécies de Asphondylia Loew, 1850 do Brazil (Diptera: Cecidomyiidae). Revista Brasileira de Entomologia 36(3): 653-661.

MAIA, V. C. 2001a. The gall midges (Diptera: Cecidomyiidae) from Three Restingas of Rio de Janeiro State, Brazil. Revista Brasileira de Zoologia 18(2): 583-629.

MaiA, V. C. 2001b. New Genera and Species of Gall Midges (Diptera: Cecidomyiidae) from Three Restingas of Rio de Janeiro State, Brazil. Revista Brasileira de Zoologia 18 (supl.1): 1-32.

MöHN, E. 1960. Gallmücken (Diptera, Itonididae) aus El Salvador. 2. Teil. Senckenbergiana Biologica 41: 197-240.

SAETHER, O. A. 1980. Glossary of chironomid morphology terminology (Diptera: Chironomidae). Entomologica Scandinavica. Suppl. 14: $1-51$.

SkuHravÁ, M. 1986. Family Cecidomyiidae, pp 72-297. In: Soós, Á. \& L. Papp, eds. 1984-1992. Catalogue of Palearctic Diptera. 4. Sciaridae-Anisopodidae. Akademiae Kiado, Budapest, 441 p.

SöLI, G. E. E. 1997. The adult morphology of Mycetophilidae (s.str.), with a tentative phylogeny of the family (Ditera: Sciaroidea). Entomologica Scandinavica. Suppl. 50: 5-55.

Tavares, J. S. 1925. Nova Contribuição para o Conhecimento da Cecidologia Brasileira. Brotéria, Série Zoológica 22:5-55, pls. I$\mathrm{V}$. 